\title{
"Para ir longe, não precisa de velocidade": uma homenagem a Raul Aragão Rocha
}

"To go far beyond, speed is not necessary?": a tribute to Raul Aragão Rocha

\section{Christiane Machado Coelho}

\section{(2) OpenEdition}

1 Journals

Edição electrónica

URL: http://journals.openedition.org/aa/1728

DOI: $10.4000 /$ aa. 1728

ISSN: 2357-738X

Editora

Programa de Pós-Graduação em Antropologia Social (UnB)

\section{Edição impressa}

Data de publição: 1 julho 2017

Paginação: 311-313

ISSN: 0102-4302

\section{Refêrencia eletrónica}

Christiane Machado Coelho, «"Para ir longe, não precisa de velocidade”: uma homenagem a Raul Aragão Rocha», Anuário Antropológico [Online], v.42 n.1 | 2017, posto online no dia 08 junho 2018, consultado o 28 abril 2021. URL: http://journals.openedition.org/aa/1728 ; DOI: https://doi.org/ 10.4000/aa. 1728

Este documento foi criado de forma automática no dia 28 abril 2021.

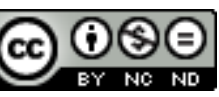

Anuário Antropológico is licensed under a Creative Commons Atribuição-Uso Não-Comercial-Proibição de realização de Obras Derivadas 4.0 International. 


\title{
"Para ir longe, não precisa de velocidade": uma homenagem a Raul Aragão Rocha
}

"To go far beyond, speed is not necessary?": a tribute to Raul Aragão Rocha

\author{
Christiane Machado Coelho
}

\section{NOTA DO EDITOR}

Recebido em : 18/11/2017 Aprovado em : 19/11/2017

Poema escrito por Raul Aragão Rocha em homenagem ao ciclista brasiliense Pedro

Davison, que morreu atropelado em 2006.

1 Raul Aragão Rocha (1993-2017), pernambucano, estudante de sociologia da Universidade de Brasília (UnB), cientista social por vocação, dedicado à questão da paz no trânsito, solidário, entusiasta, empenhado no tema da mobilidade. Membro fundador do Observatório de Brasília Metropolitana, ativista do Rodas da Paz, do Bike Anjo, interessado pela história de Brasília e pelo impacto do automóvel para os moradores dessa cidade. Ciclista experiente, foi atropelado por um carro entre a UnB e a sua casa num sábado à tarde na L2 Norte. Não suportou os graves ferimentos e faleceu no dia seguinte, 22 de outubro de 2017. Um jovem foi atropelado por um outro jovem. Um de bicicleta e o outro de carro, em alta velocidade. A questão do carro em Brasília, objeto de estudo de Raul, tem sua síntese e resposta com a sua própria vida. 0 direito à cidade, à mobilidade e à própria vida ficam evidenciados neste caso específico.

2 A questão da participação na cidade e a consolidação ou usurpação de direitos pode ser pensada no caso da mobilidade. Robert Park (1976) considera o citadino como alguém que se locomove. A mobilidade dá a medida das relações sociais e o grau de socialização de determinada população urbana. Citadino como passante e ser de passagem. 
3 Brasília é um excelente laboratório para analisar a questão urbana. Raul Aragão baseava-se na análise do projeto original de Lucio Costa, elaborado no boom da indústria automobilística na época de construção da cidade, na manutenção de um projeto de cidade baseado no automóvel particular, buscando compreender o local do carro na sociedade brasiliense, assim como suas implicações sociais.

4 Raul Aragão destacava a necessidade de mais estudos que relacionassem os ideais de concepção de Brasília com a realidade. A relação entre cidade, modernidade e automóvel é evidenciada no projeto final de sua monografia, analisando em que medida o imaginário coletivo sobre o carro se relacionava com a promessa de eficiência presente no imaginário socioeconômico da época da criação de Brasília.

5 O Plano de Metas de Kubitschek tinha como principais pilares a construção da nova capital da República e o desenvolvimento industrial, ancorado na indústria automobilística, inaugurando um ciclo em que se substituíam as importações. Estes eram requisitos para o credenciamento do Brasil na modernidade, deixando para trás a estrutura agrária ainda predominante na sociedade brasileira (Rocha Neto, 2012 :62).

6 No estudo do lugar do carro na sociedade brasiliense e suas implicações sociais, Raul Aragão tinha como hipótese de trabalho que "o motorista do automóvel particular tende a exigir o monopólio do uso do espaço urbano para si enquanto indivíduo, em conflito inclusive com seus pares" (Rocha, 2017 :2). Os conceitos de direito à mobilidade e de mobilidade ativa permeavam suas análises, com base em estudos como o de Oswaldo Assis Rocha Neto, Mobilidade urbana e cultura do automóvel na singularidade da metrópole modernista brasileira (2012), o de Lourenço Carvalho, Mobilidade urbana no Distrito Federal: um estudo do Programa Brasilia Integrada (2008), o livro de Hartmut Günther e colegas Pesquisa sobre comportamentos no trânsito (2015) e o de Jane Jacobs Morte e vida nas grandes cidades (2000).

7 Raul destacava como, no próprio projeto de Lucio Costa, havia a ausência do termo "rua" e como isto poderia influenciar a presença do carro privado ocupando a rua pública. Mencionavam-se, no projeto original das cidades, os termos "vias expressas" e “eixos". "Qualquer obstáculo encontrado frustra a "promessa de utilização do automóvel" (Rocha, $2017: 3$ ).

8 Raul Aragão baseava-se na ideia de Rocha Neto (2012) de como a socialização centrada no carro não implicava uma morte da rua, mas sim do pedestre. Caracterizava este processo como um novo tipo de socialização : "o modelo de mobilidade urbana baseado no carro precisa ser reestruturado e ter seu caráter prioritário questionado", de forma a garantir o direito à cidade postulado por Lefebvre (Rocha, $2017: 4$ ).

9 Os modelos de cidade e de sociedade, as implicações da mobilidade baseada no automóvel particular e a própria ideia de carro como modelo estruturador da vida coletiva e de mobilidade precisam ser revistos em termos de projetos políticos e sociais e da questão do direito à mobilidade como direito à cidade.

10 O caráter monumental, bucólico, e as extensas áreas verdes em Brasília que estavam presentes no projeto original de Lucio Costa poderiam ser atualizados, permitindo ampliar as formas de mobilidade e de acesso à cidade. O próprio Raul destacava a necessidade de "alcançar o equilíbrio entre os diversos modos de transporte em Brasília, através da negação da primazia do transporte individual motorizado" (Rocha, $2017: 3)$. 
11 Pensando o lugar do carro na sociedade brasiliense, a mobilidade como direito e a influência da política pública na visão popular dos principais atores envolvidos no uso da bicicleta como meio de transporte, precisamos manter viva a memória de Raul Aragão como cientista social, como sociólogo urbano em potencial, como pessoa, ciclista, ativista da paz no trânsito, como alguém envolvido com a recuperação histórica atualizada da cidade de Brasília. Fica o pensamento de Raul.

Raul presente.

\section{BIBLIOGRAFIA}

CARVALHO, Lourenço. 2008. Mobilidade urbana e cidadania no Distrito Federal : um estudo do Programa Brasília Integrada. Dissertação de mestrado, Universidade de Brasília.

GÜNTHER, Hartmut et al. (Orgs.). 2015. Pesquisas sobre comportamento de trânsito. São Paulo : Casa do Psicólogo.

JACOBS, Jane. 2000. Morte e vida nas grandes cidades. São Paulo : Martins Fontes.

PARK, Robert Ezra. 1976. “A cidade : sugestões para a investigação do comportamento humano no meio urbano". In : Otávio Guilherme Velho (org.). o fenômeno urbano. Rio de Janeiro : Zahar. pp. 25-66.

ROCHA, Raul Aragão. 2017. A significação do carro na construção de Brasília. Projeto de pesquisa de monografia, Universidade de Brasília.

ROCHA NETO, Oswaldo Assis. 2012. Mobilidade urbana e cultural do automóvel na singularidade da metrópole modernista brasileira. Dissertação de mestrado, Universidade de Brasília.

\section{AUTOR}

\section{CHRISTIANE MACHADO COELHO}

Christiane Machado Coelho é professora adjunta II do Departamento de Sociologia da UnB com especialidade na área de sociologia urbana. Contato : christianemcoelho[at]gmail.com 